\title{
Quality of honeybee drones reared in colonies with limited and unlimited access to pollen
}

\author{
Krystyna Czekońska $^{1}$, Bożena ChudA-Mickiewicz ${ }^{2}$, Jerzy SAmborski ${ }^{2}$ \\ ${ }^{1}$ Department of Pomology and Apiculture, Agricultural University, 29 Listopada 54, 31-425, Krakow, Poland \\ ${ }^{2}$ Department of Zoology and Apiculture, West Pomeranian University of Technology, Doktora Judyma 20, 71-466, \\ Szczecin, Poland
}

Received 5 December 2013 - Revised 31 March 2014 - Accepted 13 May 2014

\begin{abstract}
Older larvae of honeybee drones are fed with a diet containing pollen. It is not known how pollen deprivation during the larval development of drones might affect their reproductive quality. This study investigated ejaculation ability and semen quality in drones reared in colonies with limited (LP) and unlimited (ULP) access to pollen. Access to pollen was limited by pollen traps. Drone brood rearing was not instantly abandoned in colonies with limited access to pollen. Colonies from the LP group reared drones with smaller mass, which ejaculated in fewer numbers and released smaller amounts of semen. The LP and ULP groups did not differ in semen quality as judged by the concentration, number, and viability of spermatozoa in ejaculate. It was found that access to pollen during larval development directly affects the reproductive quality of drones.
\end{abstract}

\section{Apis mellifera / drone / pollen / semen quality}

\section{INTRODUCTION}

Under moderate climate, honeybee drones (Apis mellifera) are present in colonies from May to August (Free and Williams 1975; Boes 2010). Their number in a colony does not exceed $10 \%$ of the adult population and depends on the stage of the season, the number of individuals in the colony, the presence and age of the queen, the number of drone brood, and the amount of food available (Allen 1963; Free and Williams 1975; Page and Peng 2001; Currie 1987; Wharton et al. 2007, 2008; Boes 2010; El-Kazafy and AL-Kahtani 2013). Only a few drones die after mating with the queen bee (Bishop 1920). Most drones, whose average lifespan is 30 days, die of other causes (old

Corresponding author: K. Czekońska,

k.czekonska@ogr.ur.krakow.pl

Manuscript editor: David Tarpy age, predation, environmental factors, nutrition, temperature, etc.) (Free and Williams 1975; Fukuda and Ohtani 1977; Rueppell et al. 2005; Wharton et al. 2007, 2008; Boes 2010).

In a honeybee colony, a drone is responsible for producing semen and transmitting it to the queen during the mating flight. Spermatozoa are produced during drone development, which lasts 24 or 25 days depending on rearing temperature (Jay 1963; Fukuda and Ohtani 1977; Czekońska et al. 2013a). Production of spermatozoa starts at the larval stage and finishes at the pupal stage (Bishop 1920). In the first days of a drone's imaginal life, spermatozoa are transported to the seminal vesicles where they remain until mating with the queen (Bishop 1920; Woyke 1958). After emergence, drones mature in the nest for 10-12 days (Woyke 1958; Ruttner and Tryasko 1976). Drones mate with the queen at the age of 15-23 days, the average being 21 days (Couvillon et al. 2010). 
During their ontogenetic development, drones are fed with royal jelly enriched with pollen; its composition is modified to suit the age of the larvae (Haydak 1970; Matsuka et al. 1973; Hrassnigg and Crailsheim 2005). After emergence, the young drones are still fed with protein- and amino acid-rich food by workers (Free 1957; Haydak 1970; Schmickl and Crailsheim 2004). Drones also eat pollen during the first 6 days of their imaginal life (Free 1957; Szolderits and Crailsheim 1993). Drones older than 7 days feed on carbohydrate-rich honey (Free 1957). Given their mass, drone larvae need considerably more food, with a more diverse protein composition, than worker bee larvae do (Haydak 1970; Gontarski 1954; Winston 1987).

Adverse weather or too intense production in an apiary sometimes has an adverse effect on brood rearing and development. A lack of honey in the nest is likely to disrupt the bee nest thermoregulation (Winston 1987). A lack of pollen supply leads to deterioration or even cessation of colony development (Allen and Jeffree 1956; Imdorf et al. 1998; Crailsheim 1990; Schmickl and Crailsheim 2004). Under pollen deprivation, brood rearing in a colony is at first limited (Imdorf et al. 1998; Seeley 2002; Seeley and Mikheyev 2003; Hrassnigg and Crailsheim 2005); later, eggs and young larvae are eaten, and cells with older bee larvae are more rapidly sealed (Woyke 1977; Schmickl and Crailsheim 2001, 2002, 2004; Boes 2010). Colonies used for pollen harvesting behave similarly. These colonies rear far fewer offspring than those kept without pollen traps (Webster et al. 1985).

The consequences of a deficiency of pollen in a bee nest have been studied in terms of worker behavior (Allen and Jeffree 1956; Fewell and Winston 1992; Eckert et al. 1994; Schmickl et al. 2003; Schmickl and Crailsheim 2004; Willard et al. 2011), worker quality (Crailsheim 1990; Hrassnigg and Crailsheim 1998; Imdorf et al. 1998; Mattilda and Otis 2006) and population health (Brodschneider and Crailsheim 2010; Foley et al. 2012; Huang 2012; Di Pasquale et al. 2013). Although drones have a substantial influence on the queen's reproductive value and the time of her use (Winston 1987; Chuda-Mickiewicz and Prabucki 1993; Boes 2010), much less attention has been paid to drones and their reproductive value under protein food deprivation in the nest (Stürup et al. 2013).

Drones are reared in large numbers only by colonies with abundant food resources (Fukuda and Ohtani 1977; Currie 1987; Seeley 2002; Seeley and Mikheyev 2003; Rueppell et al. 2006; Hrassnigg and Crailsheim 2005; Boes 2010). Drones reared in colonies that accumulate more pollen are more active and initiate flight earlier (Rueppell et al. 2006). They do not require additional pollen nutrition during their sexual maturation (Stürup et al. 2013).

The studies conducted to date have been concerned mostly with comparing the reproductive value of small drones reared in worker cells and large drones reared in drone cells (Berg et al. 1997; Schlüns et al. 2003; Gençer and Firatli 2005; Couvillon et al. 2010; Gençer and Kahya 2011). Among other findings, it has been shown that larger, heavier drones produce more semen with higher quality spermatozoa and are more successful at mating (Schlüns et al. 2003; Gençer and Firatli 2005; Koeniger et al. 2005; Couvillon et al. 2010; Gençer and Kahya 2011).

It is not known how pollen deprivation during the larval development of drones might affect their reproductive value. The nutrition of drones during their larval development might have effects on their body mass, ability to evert the copulatory apparatus and ejaculate, or the number and viability of their spermatozoa. In this study, we compared ejaculation ability and semen quality in drones reared in colonies with limited or free access to pollen.

\section{MATERIAL AND METHODS}

The experiments were done during two beekeeping seasons (May and June 2012 and 2013) and used drones reared in honeybee (A. mellifera) colonies kept in an apiary near Krakow in Garlica Murowana, Poland (lat.: 50.140382, long.: 19.930825). Drones were reared in colonies with limited or free access to 
pollen. Each experiment used six bee colonies occupying Wielkopolski hives with $360 \times 260 \mathrm{~mm}$ frames of a type commonly used in Poland. Each colony contained a 2-year-old queen naturally inseminated, about 40,000 workers, and 20 wax combs ( 8 worker combs filled with brood in all stages of development, 11 combs with food, and 1 experimental drone comb). All hives were fitted with bottom pollen traps with $5.0-\mathrm{mm}$ diameter holes, providing no more than $60 \%$ trapping efficiency (Keller et al. 2005). The maintained level of pollen trapping ensured that a sufficient number of drones were reared for the experiments. The pollen traps were activated in only three experimental colonies 7 days prior to the experiment. In the other three colonies, the traps were kept constantly open. The experimental colonies inhabiting hives with active traps are abbreviated LP (limited access to pollen), and the control colonies inhabiting hives with inactive traps are labeled ULP (unlimited access to pollen). The experiments were run four times, twice each season.

Queens in all colonies were caged on drone combs 7 days after the pollen traps were activated, and $24 \mathrm{~h}$ later, the queens were released and the combs with eggs were isolated to prevent the queen from laying eggs on them again. When the brooded cells were sealed, the pollen traps were deactivated. Up to that time, the pollen pellets had been systematically collected from the traps and weighed.

On the 23rd day after egg-laying, the combs with drone brood were photographed, tagged, and then placed in cages which were subsequently incubated at $34{ }^{\circ} \mathrm{C}$. During the next $24 \mathrm{~h}$, the time of drone emergence was checked at 6-h intervals. The first 30 emerged drones were weighed, and the others emerging during those $24 \mathrm{~h}$ were put in isolators in the bee colonies, where they remained to the end of the study. The isolators were made of queen-excluder material having small openings which prevented the drone but not the workers from passing through. The drones stayed in the colonies until they were 15 days old.

The drones were transported to the laboratory together with workers in cages $(130 \times 115 \times 70 \mathrm{~mm})$ supplied with Apifonda candy. In the laboratory, the bees were given water additionally.

The number of drones reared on the isolated combs was recorded throughout the study. The emerged drones' body mass was measured and their thorax mass in the second year of the study. On day 15 of their life, the proportion of drones everting the copulatory apparatus and ejaculating was determined. The semen quality of each drone was evaluated on the basis of ejaculate volume, spermatozoa concentration per $1 \mu \mathrm{L}$, and spermatozoa viability. Spermatozoa viability was measured as the proportion of live spermatozoa in the obtained semen.

Pollen pellets collected systematically from the LP colonies were weighed (Medicat 1600C scale, $0.1 \mathrm{~g}$ accuracy). The number of capped drone brood cells was counted from photographs taken with a Nikon D70 camera 1 day before the expected emergence of drones. The number of brooded cells in each photograph was counted using GIMP 2.8 software (GNU Image Manipulation Program). Drone mass was determined as the mean of 30 individuals from each colony. Those drones were anesthetized with $\mathrm{CO}_{2}$ and decapitated, after which, the abdomens were removed and the thoraces were weighed. Drone body and thorax weight were measured individually with MATTLER TOLEDO XP scales to $0.001 \mathrm{mg}$ accuracy.

The degree of eversion of the copulatory apparatus was assessed by provoking the organ to evert by slightly bending the thorax and pressing it with the fingers, following the method described by Cobey et al. (2013). After eversion of the copulatory apparatus and exudation of semen, the semen was collected in a calibrated microcapillary of known diameter. The length of the microcapillary filled with semen was then measured and converted to volume; $14.3-\mathrm{mm}$ length of the capillary was taken to equal $1-\mu \mathrm{L}$ semen. The semen was collected using a microcapillary calibrated to $1 \mu \mathrm{L}$. The volume of semen was determined by measuring the filled length of the capillary with calipers. Semen volume was determined to $0.1-\mu \mathrm{L}$ accuracy. The drones were always examined by the same experimenter. In total, 330 drones (183 LP, 147 ULP) were used in assessing readiness to evert the copulatory apparatus and ejaculate.

Spermatozoa concentration per $1-\mu \mathrm{L}$ semen was determined using the modified method of Woyke (1979). Semen in a known volume was transferred from microcapillaries to tubes which then were filled with saline solution, maintaining a 1:2,000 ratio. 
After mixing thoroughly, the semen solution was diluted 1:8,000 with distilled water. Spermatozoa were counted in photographs of ten large squares in a Fuschs-Rosenthal chamber taken with a Zeiss Primo Star microscope using Scope Photo software. The number of spermatozoa in $1-\mu \mathrm{L}$ semen was counted from a total of $35 \mathrm{LP}$ and 37 ULP drone semen samples.

Semen intended for spermatozoa viability assays was diluted in 1,000 $\mu \mathrm{L} \mathrm{Kiev} \mathrm{buffer.} \mathrm{The} \mathrm{percentages}$ of live and dead spermatozoa in each sample were determined by SYBR-14/propidium iodide (IP) fluorescence staining with the LIVE/DEAD Sperm Viability Kit (Molecular Probes L-7011). Each $1 \mu \mathrm{L}$ semen sample was mixed with $5 \mu \mathrm{L}$ 1:50 diluted Syber-14 and incubated in the dark for $10 \mathrm{~min}$, after which, $2-\mu \mathrm{L}$ propidium iodide was added and the mixture was incubated for another $10 \mathrm{~min}$. Then, 5$\mu \mathrm{L}$ incubated semen solution was placed on a glass slide for microscopy. The number of live and dead spermatozoa was counted using an Axio Imager M2 fluorescence microscope. Fifteen fields per preparation were photographed. All samples were prepared and processed in the same way. The obtained images were also analyzed in the same way using AxioVision LE software. The number of live and dead spermatozoa was counted from a total of 19 LP and 15 ULP semen samples.

Differences in the number of drones reared, their body and thorax masses, and the thorax to body mass ratio was tested for significance by nested ANOVA. The $G$ test was used to test differences in the proportions of drones everting the copulatory apparatus and ejaculating (Sokal and Rohlf 1981). Differences in semen volume, concentration of spermatozoa per $1 \mu \mathrm{L}$ semen, number of spermatozoa in the collected semen, and spermatozoa viability were analyzed using Student's $t$ test. Percentage data were arcsin-transformed. Statistical analyses were performed using Statistica ${ }^{\text {TM }}$ software (StatSoft 2013). Differences were considered significant at $P=0.05$, and the results are reported as means \pm SD.

\section{RESULTS}

The amount of pollen collected from colonies with limited access to pollen (LP) ranged from 215 to $1,290 \mathrm{~g}$, (avg. 932 \pm 730 g per colony).
Statistical analyses showed no effect of year on any tested parameter, allowing us to combine the data and present it in Table I by experimental group only.

Of the 24 colonies used in this study, one LP colony and one ULP colony reared no drones. The LP and ULP colonies had similar numbers of cells with drone brood on the isolated combs, ranging from 28 to 670 . There were no differences between groups or between replicates $\left(\mathrm{F}_{(3,17)}=2.347, P=0.109\right)$ in the amount of brood reared (Table I).

In the first year, we weighed 267 drones from 10 colonies, and in the second, 356 drones from 12 colonies. Average drone body mass in the LP group was $8 \mathrm{mg}$ lower than in the ULP group, a statistically significant difference (Table I). Also significant were differences in drone body mass between replicates $\left(\mathrm{F}_{(3,619)}=12.410, P<0.001\right)$.

The average thorax mass of drones from the LP group was $7.3 \mathrm{~g}$ lower than that of the ULP group, and this difference was statistically significant (Table I). The thorax to body mass ratio was slightly lower in drones from the LP group versus the ULP group; the difference was on the borderline of statistical significance (Table I).

The proportion of drones everting the copulatory apparatus was $92 \%$ for the LP group and $87 \%$ for ULP (Figure 1). In the LP group, $68 \%$ of the drones everting the copulatory apparatus ejaculated and $12 \%$ less than in the ULP group; drones from the LP group had significantly more difficulty with ejaculation than those from the ULP group $\left(\mathrm{G}_{\mathrm{adj}}=20.855, \mathrm{df}=4, P<0.001\right)$.

Semen volume was estimated using 244 portions of semen from both LP and ULP drones (Table I). On average, significantly less semen $0.2 \mu \mathrm{L}$ (drone on average) was collected from LP drones than from ULP drones.

The spermatozoa concentration per $1-\mu \mathrm{L}$ semen did not differ significantly between the LP and ULP drones (Table I) nor did the number of spermatozoa differ. The semen from the LP and ULP drones showed similar levels of spermatozoa viability, with no significant difference (Table I). 
Table I. Average values $( \pm \mathrm{SD})$ of traits investigated in drones from groups with limited and unlimited access to pollen.

\begin{tabular}{llcccr}
\hline Trait & Number & $\begin{array}{l}\text { Limited access } \\
\text { to pollen }\end{array}$ & $\begin{array}{l}\text { Unlimited access } \\
\text { to pollen }\end{array}$ & Statistic & $P$ value \\
\hline $\begin{array}{l}\text { Number of drone cells } \\
\text { with brood present }\end{array}$ & 22 & $163 \pm 110$ & $258 \pm 192$ & $\mathrm{~F}_{(1,17)}=3.300$ & 0.087 \\
Body weight $(\mathrm{mg})$ & 624 & $254 \pm 20.3$ & $262 \pm 18.9$ & $\mathrm{~F}_{(1,619)}=23.47$ & $<0.001$ \\
Thorax weight $(\mathrm{mg})$ & 357 & $99.7 \pm 18.2$ & $107.0 \pm 6.3$ & $\mathrm{~F}_{(1,354)}=25.47$ & $<0.001$ \\
Thorax/body weight & 357 & $0.408 \pm 0.3$ & $0.413 \pm 0.2$ & $\mathrm{~F}_{(1,354)}=4.00$ & 0.047 \\
Semen volume $(\mu \mathrm{L})$ & 244 & $0.9 \pm 0.27$ & $1.1 \pm 0.79$ & $\mathrm{t}_{(242)}=2.795$ & 0.006 \\
Sperm concentration & 72 & $5.666 \pm 1.47$ & $5.456 \pm 1.01$ & $\mathrm{t}_{(70)}=0.831$ & 0.409 \\
$\quad\left(\times 10^{6} / \mu \mathrm{L}\right)$ & 72 & $5.138 \pm 1.45$ & $5.815 \pm 2.00$ & $\mathrm{t}_{(70)}=-1.727$ & 0.089 \\
Sperm count & 34 & $97.9 \pm 13.9$ & $98.8 \pm 1.23$ & $\mathrm{t}_{(32)}=0.792$ & 0.434 \\
Sperm viability $(\%)$ & & & & & \\
\hline
\end{tabular}

\section{DISCUSSION}

Limiting the bee colonies' access to pollen 10 days before the start of drone larvae rearing did not affect the number of drones reared but led to a decrease in their body and thorax mass. A slight decrease in the thorax to body mass ratio was also noted. Drones reared in LP colonies were physically less able to ejaculate and released less semen than those from the ULP colonies. The two treatment groups did not differ in semen quality.

To explain the lack of a between-treatment difference in the amount of drone brood reared, we note the relatively short period of pollen supply deprivation in our protocol. Schmickl and Crailsheim (2001) observed the first signs of brood rearing limitation after 5 days, but with the pollen supply to the nest completely blocked. In our study, the only differences in the amount of brood reared were between replicates due primarily to weather conditions during successive experiments and also the condition of the colonies (Currie 1987; Schmickl and Crailsheim 2004; Boes 2010).

Drone body mass in both the LP and ULP groups corresponded to the average drone mass reported in publications and ranged between 201 and $290 \mathrm{mg}$ (Woyke 1978; Gençer and Firatli 2005; Hrassnigg and Crailsheim 2005; Mazeed and Mohanny 2010; Gençer and Kahya 2011), but the LP drones had lower mass than

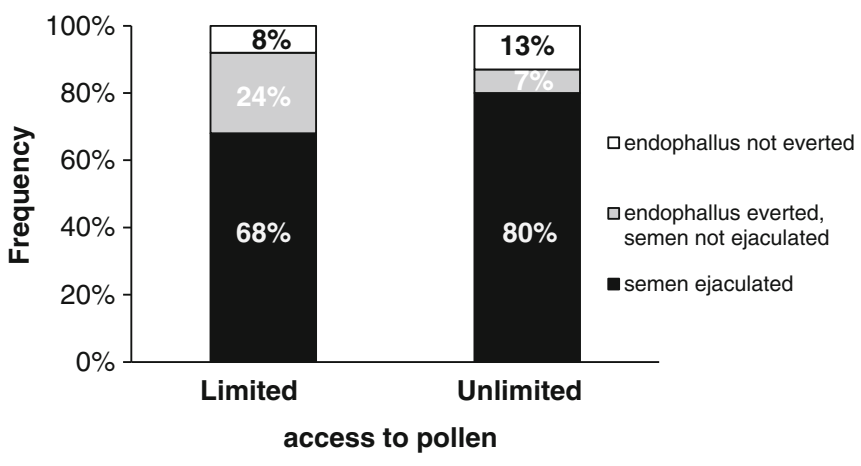

Figure 1 Percentage of drones everting the copulatory apparatus and ejaculating semen when probed manually among those reared in colonies with limited or unlimited access to pollen. 
the ULP drones. The thorax to body mass ratio of the LP drones was also slightly lower. Both of those outcomes might be the first symptoms of LP drones' poorer development. Their lower thorax to body mass ratio may indicate reduced mass of thorax muscles, a component of male's physical fitness. Drones with larger thorax mass in proportion to body mass have been suggested to be stronger and more agile in flight, which should increase the success of their nuptial flights (Coelho 1996; Kraus et al. 2003; Slone et al. 2012).

Drones reared in the LP colonies everted the copulatory apparatus but ejaculated less frequently and released smaller amounts of semen than the ULP drones. Possibly, the LP drones at 15 days of age had no semen or were sexually immature and not yet able to ejaculate so that they released small amounts of semen if any. Perhaps drones from colonies with limited access to pollen do not participate in reproduction and die quickly or have a shorter reproductive period. Our results could help explain the reported large differences in the reproductive success of drones from different colonies (Kraus et al. 2003; Rueppell et al. 2006; Couvillon et al. 2010), and differences in the number of drones needed to collect one dose of semen for queen bee insemination (Woyke 1960, 2010; Chuda-Mickiewicz and Prabucki 1993; Rhodes et al. 2011).

The range of volume of semen we measured from the drones is comparable to that reported in other studies (0.1 to $1.8 \mu \mathrm{L}$ ) (Woyke 1960; Chuda-Mickiewicz and Prabucki 1993; Schlüns et al. 2003; Rhodes et al. 2011; Gençer and Kahya 2011; Czekońska et al. 2013a), but the concentration of spermatozoa was lower. Regardless of the treatment group, in $1-\mu \mathrm{L}$ semen, we estimated more than two million fewer spermatozoa than the reports of Woyke (1960), Mackensen (1964), Bobrzecki (1968), and Gençer and Kahya (2011), who obtained 7.5, 7.64, 7.36, and 7.26 million, respectively. Chuda-Mickiewicz and Prabucki (1993) gave figures closer to ours: 4.9 to 6.1 million spermatozoa per $1 \mu \mathrm{L}$. There were no differences in spermatozoa concentration between the LP and ULP drones.
The drones from the two groups did not differ in number of spermatozoa. Our figures agree with the averages, ranging between 1.1 and 12.4 million, reported elsewhere (Woyke 1960; Schlüns et al. 2003; Gençer and Firatli 2005; Koeniger et al. 2005; Mazeed and Mohanny 2010; Gençer and Kahya 2011; Rhodes et al. 2011). Experimentally limiting the bees' access to pollen did not affect the concentration and number of spermatozoa in drone semen nor were there any differences in spermatozoa viability between the LP and ULP groups. It was high in both groups and comparable to literature results (Collins and Donoghue 1999; Locke and Peng 1993; Shafir et al. 2009; Gençer and Kahya 2011; Tofilski et al. 2012; Czekońska et al. 2013a, b), considerably exceeding $80 \%$.

We found that honeybee colonies do not immediately abandon drone brood rearing when access to pollen is limited. Workers rear a brood that produces drones with lower mass, ejaculating less frequently, and giving smaller volumes of semen. The LP colonies did not rear brood with lower semen quality, however, as judged by the spermatozoa concentration and by the number and viability of spermatozoa in the ejaculate.

Bee workers seal the cells of worker larvae earlier in response to a halt in pollen supply (Schmickl and Crailsheim 2001, 2002, 2004). They might do the same in rearing a drone brood. The lower body mass, less frequent ejaculation, and lower volume of semen from the drones of experimental colonies with limited access to pollen, shown in this study, may have been due to drone larvae malnutrition caused by faster sealing of cells. Deteriorating nutritional conditions are likely to have compromised the drones' physical ability to copulate, but they did not reduce semen quality. The mechanism regulating drone rearing is not fully understood, but our results suggest that it depends largely on pollen accessibility, a suggestion supported by other studies (Fukuda and Ohtani 1977; Currie 1987; Seeley 2002; Seeley and Mikheyev 2003; Schmickl and Crailsheim 2004; Rueppell et al. 2006; Hrassnigg and Crailsheim 2005; Boes 2010). 
In this work, $32 \%$ of the drones reared in nutritionally poorer conditions and $20 \%$ of those fed normally had problems in everting the copulatory apparatus and ejaculating. Drones reared under poorer nutrition probably mature later and delay their nuptial flights. The briefer reproductive period lowers their chance of mating with the queen, reducing the likelihood of delivering semen to her.

\section{ACKNOWLEDGMENTS}

This study was financed by the National Science Centre funds allotted based on decision no. DEC2011/01/B/NZ9/00213. We thank two anonymous reviewers for the helpful advice on this manuscript.

\section{OPEN ACCESS}

This article is distributed under the terms of the Creative Commons Attribution License which permits any use, distribution, and reproduction in any medium, provided the original author(s) and the source are credited.

\section{La qualité des mâles d'abeilles élevés dans des colonies ayant un accès restreint ou illimité au pollen}

\section{Apis mellifera / approvisionnement / qualité du sperme}

\section{Die Qualität von Honigbienendrohnen in Völkern mit beschränktem und unbeschränktem Zugang zu Pollen}

\section{Apis mellifera / Drohnen / Pollen / Samenqualität}

\section{REFERENCES}

Allen, M.D. (1963) Drone production in honey-bee colonies (Apis mellifera L.). Nature 199, 789-790

Allen, M.D., Jeffree, E.P. (1956) The influence of stored pollen and of colony size on the brood rearing of honeybees. Ann. Appl. Biol. 44, 649-656

Berg, S., Koeniger, N., Koeniger, G., Fuchs, S. (1997) Body size and reproductive success of drones (Apis mellifera L.). Apidologie 28, 449-460
Bishop, G.H. (1920) Fertilization in the honey-bee. I. The male sexual organs: Their histological structure and physiological functioning. J. Exp. Zool. 31, 224-265

Bobrzecki, J. (1968) Badania nad wpływem wychowu na dojrzałość płciową trutni i ich przydatność do sztucznego unasieniania [in Polish]. [Studies on the effects of rearing on the sexual maturity of drone and their suitability to artificial insemination]. Zeszyty Naukowe Wyższej Szkoły Rolniczej w Olsztynie 24(624), 197-220

Boes, K.E. (2010) Honeybee colony drone production and maintenance in accordance with environmental factors: an interplay of queen and worker decisions. Insectes Soc. 57, 1-9

Brodschneider, R., Crailsheim, K. (2010) Nutrition and health in honey bees. Apidologie 41, 278-294

Chuda-Mickiewicz, B., Prabucki, J. (1993) Próba określenia wpływu pory wychowu trutni na wartość inseminowanych matek [in Polish] [An attempt to ascertain the influence of the drone rearing time on volume of inseminated honeybee queens]. Pszczeln. Zesz. Nauk. 37, 41-49

Cobey, S.W., Tarpy, D.R., Woyke, J. (2013) Standard methods for instrumental insemination of Apis mellifera queens. J. Apic. Res. . doi:10.3896/ IBRA.1.52.4.09

Coelho, J.R. (1996) The flight characteristics of drones in relation to mating. Bee Science 4, 21-25

Collins, A.M., Donoghue, A.M. (1999) Viability assessment of honey bee, Apis mellifera, sperm using dual fluorescent staining. Theriogenology 51(8), 1513-1523

Couvillon, M.J., Hughes, W.O., Perez-Sato, J.A., Martin, S.J., Roy, G.G., Ratnieks, F.L. (2010) Sexual selection in honey bees: colony variation and the importance of size in male mating success. Behav. Ecol. 21(3), 520-525

Crailsheim, K. (1990) The protein balance of the honey bee worker. Apidologie 21, 417-429

Currie, R.W. (1987) The biology and behaviour of drones. Bee World 68, 129-143

Czekońska, K., Chuda-Mickiewicz, B., Chorbiński, P. (2013a) The effect of brood incubation temperature on the reproductive value of honey bee (Apis mellifera) drones. J. Apic. Res. 52(2), 96-105

Czekońska, K., Chuda-Mickiewicz, B., Chorbiski, P. (2013b) Influence of age of honey bee (Apis mellifera) drones on volume of semen and viability of spermatozoa. J. Apic. Sci. 57(1), 61-66

Di Pasquale, G., Salignon, M., Le Conte, Y., Belzunces, L.P., Decourtye, A., Kretzschmar, A., Alaux, C. (2013) Influence of pollen nutrition on honey bee health: do pollen quality and diversity matter? PloS one 8(8), e72016

Eckert, C.D., Winston, R.C., Ydenberg, R.C. (1994) The relationship between population size, amount of brood, and individual foraging behaviour in the honey bee, Apis mellifera L. Oecologia 97, 248-255 
El-Kazafy, A.T., AL-Kahtani, S.N. (2013) Relationship between population size and productivity of honey bee colonies. J. Entomol. 10, 163-169

Fewell, J.H., Winston, M.L. (1992) Colony state and regulation of pollen foraging in the honey bee, Apis mellifera L. Behav. Ecol. Sociobiol. 30, 387-393

Foley, K., Fazio, G., Jensen, A.B., Hughes, W.O.H. (2012) Nutritional limitation and resistance to opportunistic Aspergillus parasites in honey bee larvae. J. Invert. Pathol. 111, 68-73

Free, J.B. (1957) The food of adult drone honeybees (Apis mellifera). Brit. J. Anim. Behav. 5, 7-11

Free, J.B., Williams, I.H. (1975) Factors determining the rearing and rejection of drones by the honeybee colony. Anim. Behav. 23(3), 650-675

Fukuda, H., Ohtani, T. (1977) Survival and life span of drone honeybees. Res. Popul. Ecol. 19, 51-68

Gençer, H.V., Firatli, Ç. (2005) Reproductive and morphological comparisons of drones reared in queenright and laying worker colonies. J. Apic. Res. 44(4), 163-167

Gençer, H.V., Kahya, Y. (2011) Are sperm traits of drones (Apis mellifera L.) from laying worker colonies noteworthy? J. Apic. Res. 50(2), 130-137

Gontarski, H. (1954) Untersuchen fiber die Verwertung yon Pollen und Heffe zur Bmtpflege der Honigbiene. Z. Bienenforsch. 2, 161-180

Haydak, M.H. (1970) Honey bee nutrition. Annu. Rev. Entomol. 15(1), 143-156

Hrassnigg, N., Crailsheim, K. (1998) The influence of brood on the pollen consumption of worker bees (Apis mellifera L.). J. Insect Physiol. 44(5), 393-404

Hrassnigg, N., Crailsheim, K. (2005) Differences in drone and worker physiology in honeybees (Apis mellifera). Apidologie 36, 255-277

Huang, Z. (2012) Pollen nutrition affects honey bee stress resistance. Terr. Arthropod Rev. 5, 175-189

Imdorf, A., Rickli, M., Killchenmann, V., Bogdanov, S., Wille, H. (1998) Nitrogen and mineral constituents of honey bee worker brood during pollen shortage. Apidologie 29, 315-325

Jay, S.C. (1963) The development of honeybees in their cells. J. Apic. Res. 2, 117-134

Keller, I., Fluri, P., Imdorf, I. (2005) Pollen nutrition and colony development in honey bees - part II. Bee World 86, 27-34

Koeniger, G., Koeniger, N., Tinger, S., Phiancharoen, M. (2005) Variance in spermatozoa number among Apis dorsata drones and among Apis mellifera drones. Apidologie 36, 279-284

Kraus, F.B., Neumann, P., Scharpenberg, H., van Praagh, J., Mortiz, R.F.A. (2003) Male fitness of honeybee colonies (Apis mellifera L.). J. Evol. Biol. 16, 914-920

Locke, S.J., Peng, Y.-S. (1993) The effects of drone age, semen storage and contamination on semen quality in the honey bee (Apis mellifera). Physiol. Entomol. 18, 144-148

Mackensen, O. (1964) Relation of semen volume to success in artificial insemination. J. Econ. Entomol. 57(4), 581-583

Matsuka, M., Naohisa, W., Kazuko, T. (1973) Analysis of the food of larval drone. J. Apic. Res. 12(1), 3-7

Mattilda, H.R., Otis, G.W. (2006) The effects of pollen availability during larval development on the behaviour and physiology of spring-reared honey bee workers. Apidologie 37, 533-546

Mazeed, A.M., Mohanny, K.M. (2010) Some reproductive characteristics of honeybee drones in relation to their ages. Entomol. Res. 40, 245-250

Page, R.E., Peng, C.Y.-S. (2001) Age and development in social insects with emphasis on the honey bee, Apis mellifera L. Exp. Gerontol. 36, 695-711

Rhodes, J.W., Harden, S., Spooner-Hart, R., Anderson, D.L., Wheen, G. (2011) Effects of age, season and genetics on semen and sperm production in Apis mellifera drones. Apidologie 42, 29-38

Rueppell, O., Fondrk, M.K., Page Jr., R.E. (2005) Biodemographic analysis of male honey bee mortality. Aging Cell 4, 13-19

Rueppell, O., Page Jr., R.E., Fondrk, M.K. (2006) Male behavioural maturation rate responds to selection on pollen hoarding in honeybees. Animal Behav. 71(1), 227-234

Ruttner, F., Tryasko, V.V. (1976) Anatomy and physiology of reproduction. In: Ruttner, F. (ed.) The instrumental insemination of the queen bee, pp. 11-24. Apimondia Publishing House, Bucharest

Schlüns, H., Schlüns, E.A., Van Praagh, J., Moritz, R.F.A. (2003) Sperm numbers in drone honeybees (Apis mellifera) depend on body size. Apidologie 34, 577-584

Schmickl, T., Crailsheim, K. (2001) Cannibalism and early capping: strategy of honeybee colonies in times of experimental pollen shortages. J. Comp. Physiol. A 187, 541-547

Schmickl, T., Crailsheim, K. (2002) How honeybees (Apis mellifera L.) change their brood care behaviour in response to non-foraging conditions and poor pollen conditions. Behav. Ecol. Sociobiol. 51, 415-425

Schmickl, T., Crailsheim, K. (2004) Inner nest homeostasis in a changing environment with special emphasis on honey bee brood nursing and pollen supply. Apidologie 35, 249-263

Schmickl, T., Blaschon, B., Gurmann, B., Crailsheim, K. (2003) Collective and individual nursing investment in the queen and in young and old honeybee larvae during foraging and nonforaging periods. Insectes Soc. 50, 174-184

Seeley, T.D. (2002) The effect of drone comb on a honey bee colony's production of honey. Apidologie 33, 75-86 
Seeley, T.D., Mikheyev, A.S. (2003) Reproductive decisions by honeybee colonies: tuning investment in male production in relation to success in energy acquisition. Insectes Soc. 50, 134-138

Shafir, S., Kabanoff, L., Duncan, M., Oldroyd, B.P. (2009) Honey bee (Apis mellifera) sperm competition in vitro - two are no less viable than one. Apidologie 40, 556-561

Slone, J.D., Stout, T.L., Huang, Z.Y., Schneider, S.S. (2012) The influence of drone physical condition on the likelihood of receiving vibration signals from worker honey bees, Apis mellifera. Insectes Soc. 59(1), 101-107

Sokal, R.R., Rohlf, F.J. (1981) Biometry. Freeman, New York

StatSoft (2013) Statistica version 10. StatSoft, Tulsa, Oklahoma, USA

Stürup, M., Baer-Imhoof, B., Nash, D.R., Boomsma, J.J., Baer, B. (2013) When every sperm counts: factors affecting male fertility in the honeybee Apis mellifera. Behav. Ecol. 24(5), 1192-1198

Szolderits, M.J., Crailsheim, K. (1993) A comparison of pollen consumption and digestion in honeybee (Apis mellifera carnica) drones and workers. J. Insect Physiol. 39, 877-881

Tofilski, A., Chuda-Mickiewicz, B., Czekońska, K., Chorbiński, P. (2012) Flow cytometry evidence about sperm competition in honey bee (Apis mellifera). Apidologie 43, 63-70

Webster, T.C., Thorp, R.W., Briggs, D., Skinner, J., Parisian, T. (1985) Effects of pollen traps on honey bee (Hymenoptera: Apidae) foraging and brood rearing during almond and prune pollination. Environ. Entomol. 14(6), 683-686
Wharton, K.E., Dyer, F.C., Huang, Z.Y., Getty, T. (2007) The honeybee queen influences the regulation of colony drone production. Behav. Ecol. 18, 1092-1099

Wharton, K.E., Dyer, F.C., Getty, T. (2008) Male elimination in the honeybee. Behav. Ecol. 19, 1075-1079

Willard, L.E., Hayes, A.M., Wallrichs, M.A., Rueppell, O. (2011) Food manipulation in honeybees induces physiological responses at the individual and colony level. Apidologie 42(4), 508-518

Winston M.L. (1987) The Biology of the Honey Bee. Harvard University Press.

Woyke, J. (1958) Histologiczna budowa organów rozrodczych trutnia [in Polish] [Summary: Histological structure of drone reproductive organs]. Poznańskie Towarzystwo Przyjaciół Nauk, Wydział Matematyczno-Przyrodniczy Prace Komisji Biologicznej 19, 1-51

Woyke, J. (1960) Naturalne i sztuczne unasienianie matek pszczelich [in Polish] [Summary: Natural and instrumental insemination of queen bees]. Pszczeln. Zesz. Nauk. 4, 183-275

Woyke, J. (1977) Cannibalism and brood-rearing efficiency in the honeybee. J. Apic. Res. 16, 84-94

Woyke, J. (1978) Comparative biometrical investigation on diploid drones of the honeybee. III. The abdomen and weight. J. Apic. Res. 17, 206-217

Woyke, J. (1979) Effect of the access of worker honey bees to the queen on the result of instrumental insemination. J. Apic. Res. 19, 136-143

Woyke, J. (2010) Three substances ejected by Apis mellifera drones during endophallus eversion as well as during natural matings with queen bees. Apidologie 41, 613-621 